\title{
Income and Expenses of Eighth District Member Banks - 1974
}

\author{
WILLIAM C. NIBLACK
}

ET income of 429 Federal Reserve member banks in the Eighth District increased 10 percent in 1974 , compared to a 13 percent increase in $1973 .^{1}$ Although total operating income jumped 29 percent over that of 1973, total operating expenses increased even more rapidly, paced by a 47 percent rise in interest expense and a 66 percent increase in the provison for loan losses. Eighth District member banks fared better, on average, than those in other districts; the total net income of all member banks in the nation increased by about 7 percent in $1974 .^{2}$ This increase reflects a marked slowdown from the rapid growth experienced in 1973.

Eighth District member banks were able to increase their capital slightly faster than total assets or deposits in 1974. Thus, capital ratios tended to inch up, reversing declines that had prevailed since 1969.

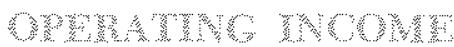

Total operating income of District member banks increased 29 percent to $\$ 1,572$ million in 1974 . About 90 percent of members banks' 1974 operating income was in the form of interest and fees from loans and securities.

Loans have accounted for an increasing share of bank assets in recent years. In 1974, however, the proportion of loans in the portfolios of member banks declined slightly. ${ }^{3}$ At the same time there was a pronounced shift in the composition of banks' loan port-

\footnotetext{
${ }^{1}$ Income and expense items in this article have been adjusted to exclude one bank. Inclusion of this bank, which experienced unusual conditions in 1974 , would have made the resulting totals for Eighth District member banks unrepresentative.

2"Member Bank Income in 1974," Federal Reserve Bulletin (June 1975), pp. 349-55.

3 All comparisons of assets, liabilities, and capital in this article are made as of December 31 of each year. Unless otherwise indicated, loans do not include Federal funds sold and securities purchased under resale agreements.
}

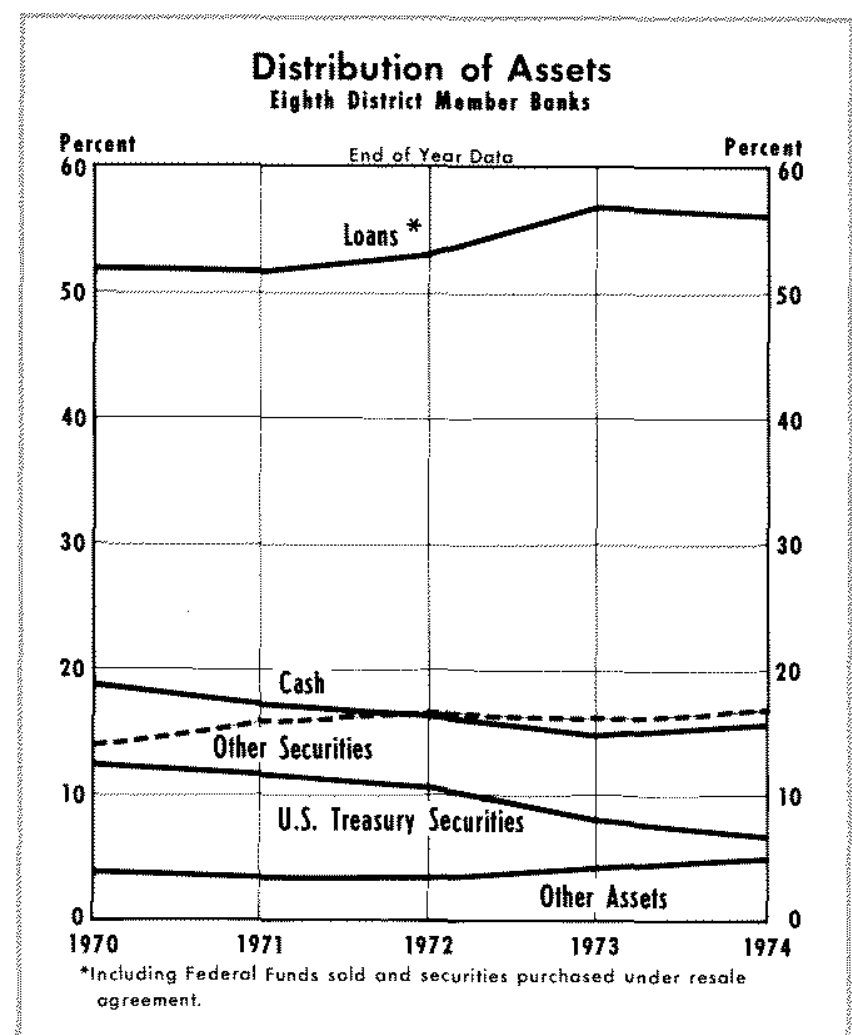

folios. Despite depressed conditions in real estate markets during much of the year, real estate loans at Eighth District member banks increased 13 percent in 1974, compared to an increase in total loans of 7 percent. Loans on farmland and conventional mort. gages on residential property (both 1-4 family and multi-family) increased at roughly the same rate as all real estate loans, while loans on commercial and industrial property increased 17 percent. Outstanding automobile installment loans contracted by 5 percent in 1974. Other consumer loans increased, however, with the most rapid growth registered in credit card and related plans, which increased 23 percent. Commercial and industrial loans, the largest single category of loans, increased 5 percent. 
Interest and fees on loans increased 29 percent to $\$ 974$ million, reflecting both the increase in loan volume and a higher realized rate of return on loans.

Income from Federal funds sold (principally overnight advances to other banks) has grown significantly in recent years, reflecting the increased use of Federal funds as a means of obtaining funds by banks as well as higher average yields on these loans. Accounting for 10 percent of member bank operating income, this source of income increased 75 percent in 1974. Even so, this rate of growth was considerably slower than the 146 percent increase experienced in 1973.

The average rate of return on loans (including Federal funds sold) for all Eighth District member banks increased to 9.3 percent from 8.7 percent in $1973 .^{4}$ The rate of return varied from 9.1 percent for banks of $\$ 5$ million to $\$ 10$ million in deposits to 10.8 percent for banks with deposits of $\$ 100$ million or more.

Another major change in bank portfolios during 1974 was the continuing decline in the share of bank assets held in U.S. Treasury securities. The amount of Treasury securities held by member banks fell by more than 9 percent. Even though the average yield on these securities increased from 6.2 to 6.6 percent, income from this source fell 3 percent. On the other hand, income from securities of U.S. Government corporations and agencies jumped 37 percent, while that from obligations of states and political subdivisions, the largest category of securities in the banks' portfolios, increased 21 percent.

Remaining categories of operating income, which are all relatively minor, increased at varying rates. Income from service charges on deposit accounts and from operation of trust departments grew less rapidly than total operating income, while that from all other sources, including other fees and service charges as well as interest on time deposits at other banks, increased 42 percent.

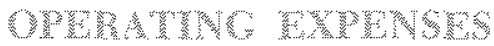

Total operating expenses of Eighth District member banks jumped 33 percent in 1974 , to $\$ 1,339$ million. Of this total, $\$ 798$ million, or 60 percent, was paid by the banks as interest. These interest expenditures were 47 percent greater than those of 1973 as both bank indebtedness and costs of funds rose.

4Averages for groups of banks presented in this article are unweighted averages of individual banks operating ratios. Balance sheet items used in constructing these ratios are averares of the figures from the Reports of Condition of December 1973 and June and December 1974. Where appropriate, the bank referred to in fr, 1 has been excluded.
The most rapidly growing category of interest expense was the cost of Federal funds purchased (that is, borrowed from other banks), which leaped 80 percent in 1974. This rapid growth in the cost of Federal funds, reflecting both the growth in the volume of funds purchased and the higher average interest rates, elevated this category to 25 percent of total interest expense.

Even with the rapid growth of expenses for Fed. eral funds, interest paid on time and savings deposits still remains by far the largest category of operating expense, accounting for 44 percent in 1974. Paralleling the changes in banks' asset structure has been a change in banks' liabilities, involving a shift from demand deposits to time and savings deposits. For example, in 1973 demand deposits accounted for 44 percent of total liabilities and time and savings deposits for 43 percent. During 1974, total demand deposits grew very little, and demand deposits of in dividuals, partnerships, and corporations (IPC demand deposits) actually fell. During the same period, total time and savings deposits increased 14 percent; much of this increase was accounted for by growth of IPC time deposits, which increased 17 percent. At the end of 1974, time and savings deposits represented 46 percent of total liabilities, while the share of demand deposits had shrunk to 41 percent.

In addition to the rapid growth of time and savings deposits, the average interest rate paid by banks on

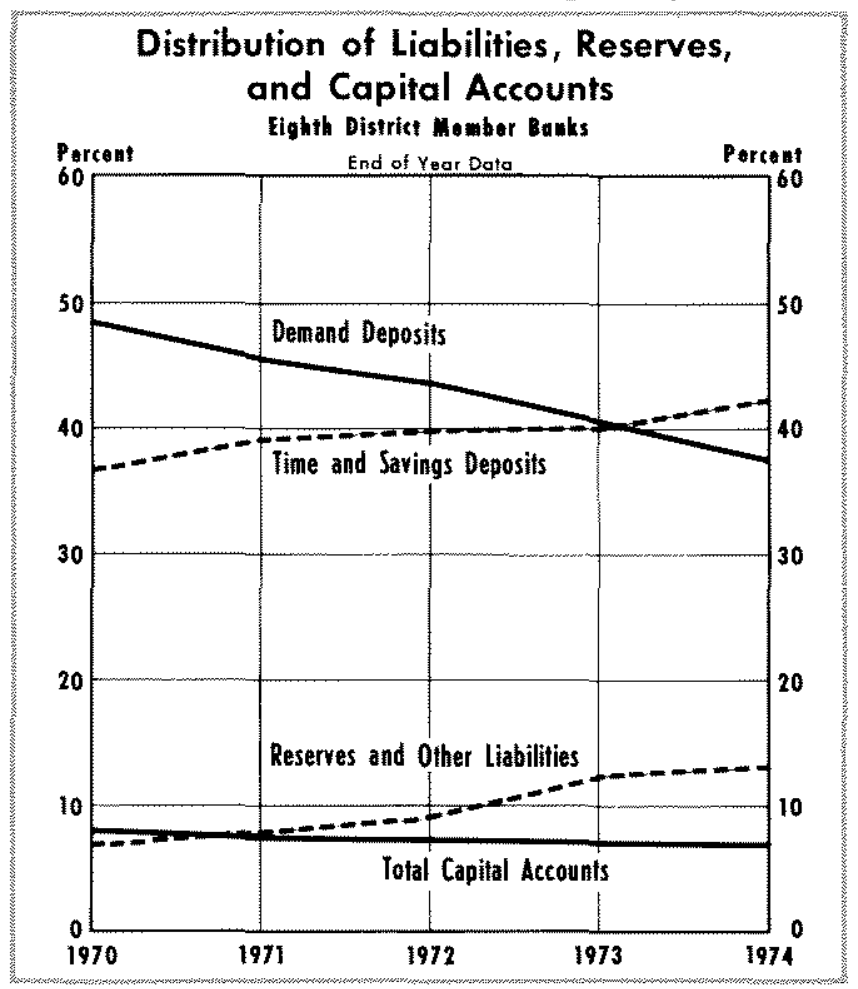


Toble 1

WNOME AND EXPENSES OF MEMBER BANKS IN THE EIGHTH FEDERAL RESERVE DISTRICT*

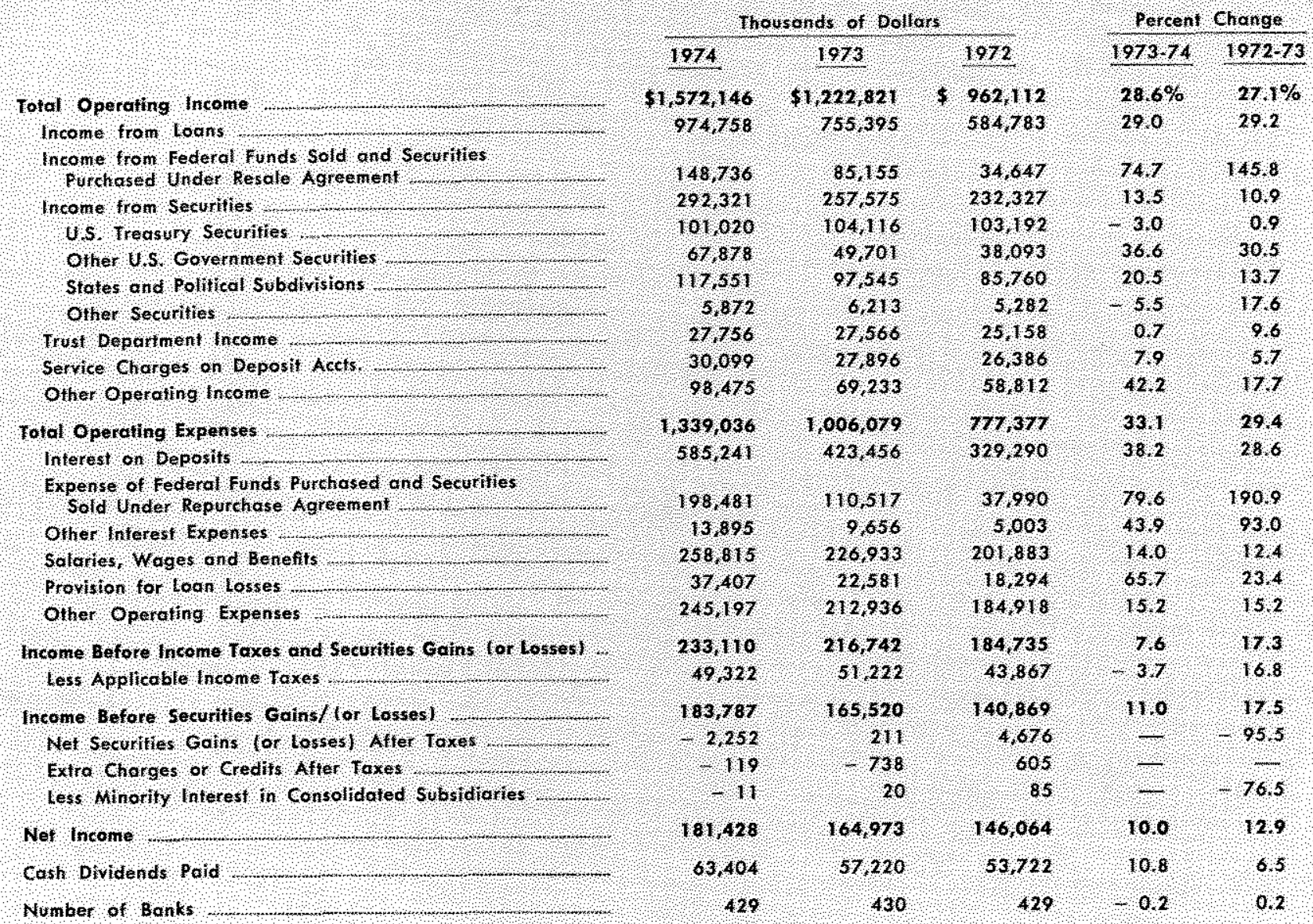

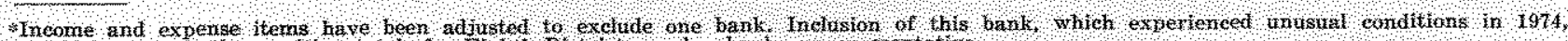

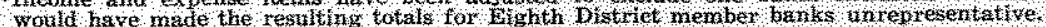

these deposits also rose, from 5.1 to 5.7 percent. As a result, the interest on deposits paid by District member banks in 1974 increased $\$ 162$ million, or 38 percent, to $\$ 585$ million. Other interest expenses of the banks, including interest on capital notes and on loans from the Federal Reserve Bank, grew almost as rapidly as interest on deposits. These other interest payments, however, were a comparatively minor portion of total operating expenses.

The second largest category of banks' operating expenses is salaries, wages, and fringe benefits of officers and employees, which totalled $\$ 259$ million, or 19 percent of operating expenses, in 1974. The 14 percent increase in this category in 1974 reflected both an increase in the number of officers and employees from 26,030 to 28,804 and a 3 percent increase in average pay and benefits.
Provision for loan losses, which is classified as an operating expense, increased dramatically in 1974, as banks increased their loan loss reserves because of larger actual losses and uncertain economic conditions. These provisions rose from $\$ 23$ million to $\$ 37$ million, representing a 66 percent increase. $\tilde{}$

Other operating expenses, including occupancy, furniture, and equipment costs, totalled $\$ 245$ million an increase of 15 percent from the previous year.

\section{Me mons}

Based on total operating income of $\$ 1,572$ million and total operating expenses of $\$ 1,339$ million, member banks had income before taxes and securities

${ }^{5}$ Actual losses charged to loan loss reserves increased from $\$ 25$ million to $\$ 41$ million. 
gains or losses of $\$ 233$ million, up 7.6 percent from 1973. When net securities losses of more than $\$ 2$ million and applicable income taxes of $\$ 49$ million are subtracted, net income of member banks in 1974 was $\$ 181$ million, up 10 percent from the year earlier.

The average rate of return on equity capital, including all reserves, declined to 12.2 percent in 1974 from 12.8 percent the year earlier. This rate varied among different sizes of banks. The highest rate of return was 12.8 percent for banks with deposits of $\$ 25-\$ 50$ million, while banks with deposits of $\$ 100$ million or over had the lowest average rate of return. Only this large bank category experienced an increase in the rate of return, from 9.5 percent in 1973 to 10.3 percent in 1974 .

Member banks paid cash dividends on common and preferred stock of $\$ 63$ million, up 11 percent from the $\$ 57$ million paid in 1973. Dividends in both 1973 and 1974 represented 35 percent of net income. This percentage also varied greatly among different sizes of banks. Banks in $\$ 5$ - $\$ 10$ million deposit category paid dividends equal to 18.6 percent of net income, whereas the biggest banks paid out 41 percent of net income in the form of dividends.

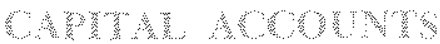

Total capital accounts of Eighth District member banks increased by $\$ 136$ million, or more than 9 percent, in 1974 to $\$ 1,597$ million at year end. The addition to capital accounts from retained earnings in 1974 was about $\$ 10$ million more than in 1973 ( $\$ 118$ million compared to $\$ 108$ million). Other net additions to capital accounts came from various comparatively minor sources. Sale of common stock was up 9 percent to $\$ 6.7$ million in 1974 , and the premium on new capital stock sold increased $\$ 3.1$ million, or 41 percent, to $\$ 10.7$ million. Common stock issued incident to mergers nearly tripled, with a par value of $\$ 3.3$ million in 1974. Mergers also led to net additions to surplus, undivided profits, and reserves of about $\$ 7$ million,

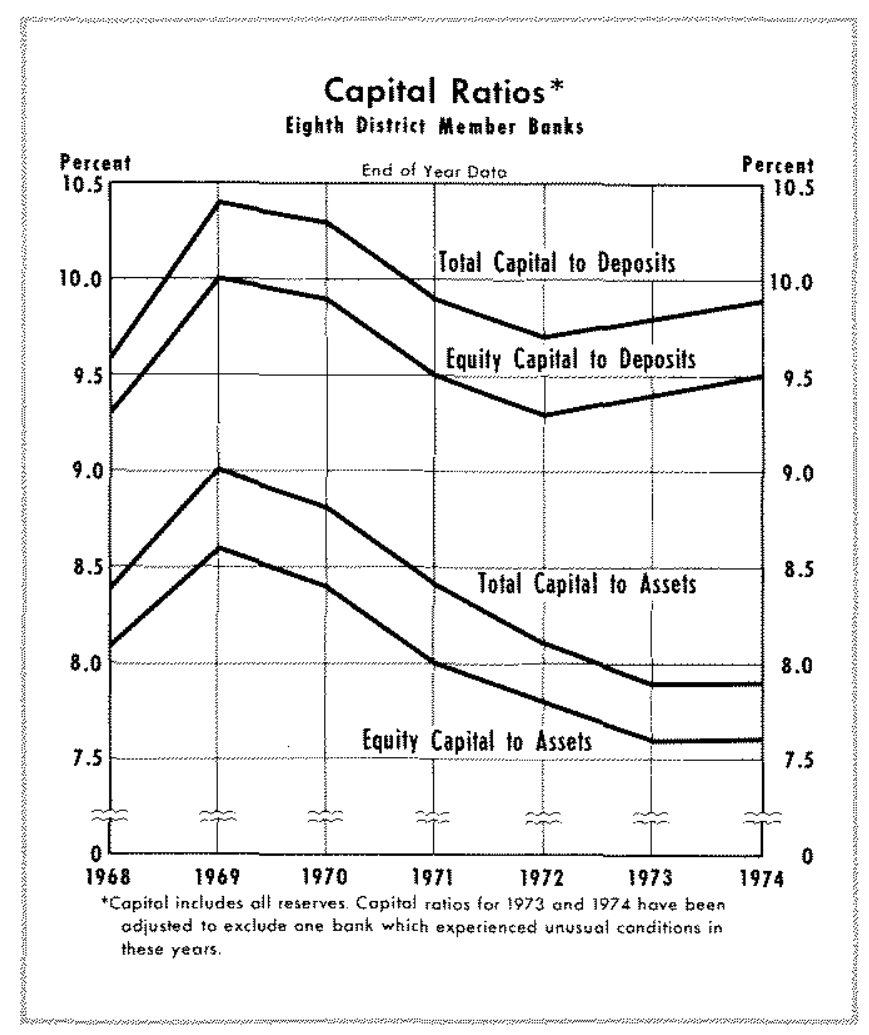

compared to less than $\$ 1$ million in 1973 . Net increases to capital accounts from all other sources totalled $\$ 3.4$ million in 1974, compared to a small net decrease in 1973. Much of this difference was accounted for by larger net transfers from undivided profits to loan loss reserves in 1973 than in 1974.

Since capital, including reserves, grew slightly more rapidly than assets or deposits, ${ }^{6}$ the ratios of capital to deposits rose in 1974 , while the capital-to-asset ratios increased slightly. The increase in capital ratios represented a reversal of the declines which have been predominant since 1969 .

\footnotetext{
Asset growth slowed to about 9 percent in 1974 from 14 percent in 1973. Deposits grew about 8 percent in 1974, compared to 10 percent in 1973. (These figures exclude the bank referred to in footnote 1 .)
} 